\title{
Translating Ancient Chinese Poems by Applying Interpretive Translation
}

\author{
Ying Wang \\ School of Foreign Language \& Cultures, Southwest University of Science and Technology, Mianyang, China \\ Email: 821622094@qq.com
}

How to cite this paper: Wang, Y. (2017). Translating Ancient Chinese Poems by Applying Interpretive Translation. Chinese Studies, 6, 29-36.

https://doi.org/10.4236/chnstd.2017.61004

Received: January 25, 2017

Accepted: February 20, 2017

Published: February 23, 2017

Copyright $\odot 2017$ by author and Scientific Research Publishing Inc. This work is licensed under the Creative Commons Attribution International License (CC BY 4.0).

http://creativecommons.org/licenses/by/4.0/ c) (i) Open Access

\begin{abstract}
This article is about a Chinese-English translation. The original text is written by one of Four Literary Eminences in the Early Tang Dynasty, Wang Bo. The purpose of this report is to discuss translating traditional Chinese poems by using interpretive translation and lay out the problems and solutions in the process of translation. Translation of the text was carried out in the following steps: intensive reading, consultation of related materials, preliminary translation, revision, finalization of the translation and writing the translation report. The narrative logic was made clear by intensive reading and the cultural confusions were resolved by referring to related materials. The whole translation is guided by the principles of faithfulness and smoothness as well as the methods of literal translation and free translation. On the completion, the version was revised and polished again and again before it is finalized. This article is mainly made up of the following parts: part one gives a brief introduction to the translation practice, including source of the text, significance and report structures; part two, practice description primarily introduces the source text, its writer, main contents and analysis; part three, translation process, including pretranslation preparation, expression stage and proofreading; the case study of the fourth part includes lexical and syntactical analysis as well as cultural key points; in the fifth part, conclusion summarizes what the translator experiences and learns through the whole process. Case analysis, the core of the article, shows in detail the difficulties, solutions and translation ideas in the translation. This article helps the translator find out her shortcomings in translation and provides suggestions for the improvement of her translation skills. More importantly, it makes the translator to realize more clearly that both Chinese and English matter for translators. Hopefully, peer translators or no matter who reads this can benefit from the article.
\end{abstract}

\section{Keywords}

Interpretive Translation, Traditional Chinese Poem, Chinese Culture 


\section{Introduction}

In this chapter, a brief introduction of the translation practice is presented, including its source, significance and structure as well as the significance of this translation practice.

\subsection{Source of the Translation Practice}

This translation practice is chosen from one of the author's translation practices, which was assigned by a teacher. After completing the translation, it suddenly occurred to the author's mind that it might be a good chance to find a way to translate traditional poems, not a universal way of course but may be suitable for some poems. The source text is from one of Wang Bo's poems: Seeing Perfect Du off to Shuzhou. The poem is written in memory of his departure with his friend when the poet himself was in Chang'an (the capital city of the Tang Dynasty) while his friend was appointed to Shuzhou. Unlike the old style of farewell poems, this one was totally different in wording and style. The third line of the poem has been orally passed down from one generation to another.

\subsection{Significance of the Translation Practice}

In China, a big family with diversified cultures, literary translation is of pivotal importance, especially in today's world. It is about a country's soft power, development and the publication of its cultures.

Since almost every Chinese, men or women, the elderly or the young, is familiar with this poem, and we are promoting our culture to the world stage, which makes it so pivotal to translate some of the most famous elements that can represent the ancient Chinese culture, poem is definitely one of them. As English majors, we not only have to master the language, but also are supposed to understand the culture behind language so that we know where an expression came from and why it should look like this. China is a country with approximately 5000 years of history. We should also present the people around the world the most known poems to the Chinese while we are translating the four great books in Chinese history.

\subsection{Structure of the Practice Report}

As exemplified by the author's thoughts and experiences of translating Seeing Perfect Du off to Shuzhou, this paper consists of four chapters. Chapter one gives a brief introduction to the translation practice, including research significance, source of practice report structure and so on.

Following this, chapter two lays a foundation for this paper by giving a general description of the pre-translation preparations regarding the source text, its writer, main contents, analysis and collection and analysis of the parallel texts. We know that comprehension of the source text is the first step to translate any texts.

Chapter three is the introduction of the adopted guiding theory and how it applies into the translation practice. 
Chapter four is translation assessments which include self-assessment, peer assessment and simulated customer evaluation. This part aims at pinpointing the problems and analyzing gains so that people can benefit from the practice.

At the conclusion part, the author summarizes what the translator experiences and learns through the whole translation process.

\section{Pre-translation Preparations}

\subsection{Introduction to the Source Text and the Author of the Source Text}

The source text is one of Wang Bo's poems-Seeing Perfect Du off to Shuzhou, which is written in memory of his departure with his friend when the poet himself was in Chang'an while his friend was appointed to Shuzhou. Unlike the old style of farewell poems, this one was totally different in wording and style.

His friend, Perfect Du, was obviously unhappy about the appointment and felt unappreciated, away from friends and relatives, from the marvelous royal court to the remote and rough southwest. The very beginning of the poem not only pinpoints the locations, but also expresses the poet's sympathy for his friend. Every line indicates the way how the poet comforted his friend and his encouragement.

Wang Bo, the celebrated poet, is the head of "Four Literary Eminence in the Tang Dynasty". The other three are Yang Jiong, Lu Zhaolin and Luo Binwang, respectively.

He was unbelievably talented since he was a kid. According to the historical records, Wang Bo can write essays at the age of 6 , therefore he was widely acclaimed and was called genius. When he was 16 , some people were jealous about his talents and set him up. As a result, he was ousted. During his three years' travel in mountains and rivers, a great number of poems and essays were produced.

$\mathrm{He}$, together with the other three, truly moved poems from the royal court to the ordinary people, from delicate pavilions to dessert in the border area. They've changed the style of then poems. Just like this poem, it is totally different from farewell poems in the past.

\subsection{Collection and Analysis of the Parallel Texts}

It is a short farewell poem, yet complicated implications were included in every word and every line. So before the translation of the poem, the author decided to collect and analyze some parallel texts, here is part of what I found:

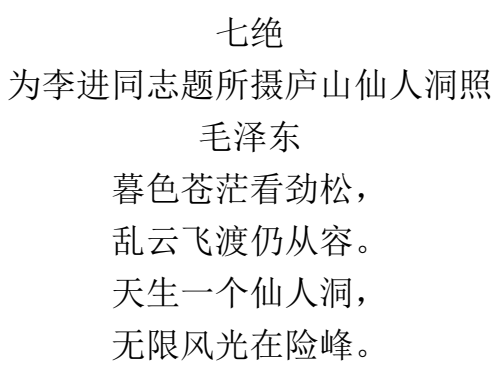


By using the interpretive translation, Mr. Gu Zhengkun, the master in translation, translated it into English:

The Immortals' Cave Inscription on a Photo Taken

By Comrade Li Jin

Lo! Standing in the dusky evening these pines sturdy keep,

So calm and quiet, withstanding billowy clouds that past sweep.

It is nature that chisels a cave for immortals antique,

The unmatched beauty dwells on the lofty and perilous peak.

As we can see, the translation process is as follows: first, understand what each line is about, then paraphrase it into mandarin and next translate it into English. Fortunately, there are no literary quotations involved. Sometimes, just one Chinese character contains several layers of meaning, which would take a lot to explain in English, but not in this poem. However, look back to the farewell poem we're going to translate, there are ancient locations in it, three in the first line, and that is why I'd choose interpretive translation, in a way I, myself, can get to know more about the history and can make it clear to foreigners. By adopting the strategy of interpretive translation, as we can see, we don't need to make sure that the number of words in every line is the same, but we do need to keep the rhyme, which is not necessarily in strict compliance with the original text.

\section{Guiding Theory and Skills Application}

\subsection{Interpretive Translation}

Interpretive translation of Peter Newmark is originated from George Steiner's hermeneutic translation theory. The theory represents the unique hermeneutic theory school in the contemporary western linguistic and translation theory. Steiner applies philosophical theory to translation studies and puts forward a systematic hermeneutic translation theory in his work After Babel. In that book, Steiner makes an unprecedented trial to apply hermeneutics theory to translation studies, and thus the relationship between translation and hermeneutics establishes.

Afterwards, these theories have been further explored and developed by a large number of scholars, such as "interpretative translation" by Peter Newmark and "interpretation as translation" by Evans-Pritchard.

Interpretive translation theory has a long history in China. Xuan Zang, a famous translator and monk applied such theory to translate Buddhist texts into Chinese. In the West, the Bible (the Greek version) can comfortably gain its reputation as the very first important version. And interpretive translation fully played its role in the whole translation process. Poetry translation is somewhat a kind of interpretation, a more comprehensive one. Specifically speaking, it is to recreate the contents, form, style and emotions by using another language. By means of such translation theory, the version can get closer as possible to the original text (Lin Huangtian, 1997).

Interpretive translation is to add some necessary interpretive words or phrases 
in translated version, that's why some people call it "explanatory translation". George Steiner wrote in his famous literature on translation, After Babel: Aspects of Language and Translation, the four steps of hermeneutic translation, they are: trust, aggression, import and compensation. We can't simply think hermeneutic translation as a way to add explanatory words, which is just a part of the translation skill. Others such as conversion, omission and affirmative \& negative expressions also belong to the skill (Yang Guoyan \& Zhang Xinmin, 2005).

For example, the ancient Chinese saying, 三个臭皮匠赛过诸葛亮, can be translated as "Three cobblers make one Zhu geliang". The version is fluent and very much faithful to the original text (Yang Guoyan \& Zhang Xinmin, 2005). There is just one problem that foreigners can't understand because the version keeps the form but loses the core meaning. They may ask questions like what the relationship between Zhu Geliang and cobblers is or who Zhu Geliang is. In light of this, we can adopt another translation skill. See the following version: Three cobblers, with their wits combined, equal Zhuge Liang, the master mind. By adding two phrases, the version is understandable to foreigners. With these two phrases, they are able to appreciate the connotation of the saying.

\subsection{Skills Application}

"The role of language within a culture and the influence of culture on the meanings of words and idioms are so pervasive that scarcely can any text be adequately understood without careful consideration of its cultural background" (Nida, 2001). In light of this, the first step of this translation should be translating all the nouns with cultural background into their today's common use.

Basically, the skills are applied as follows; first of all, each and every phrase will be interpreted from the ancient names to their today's counterparts, especially those with profound cultural connotations. Then linking words into sentences and trying to figure out what the poet tried to express. And finally, translating them into English with the least meaning lost as possible as I can.

The word “少府” in the title of the poem refers to a governmental position in China which has no corresponding translation in English. After searching all the English versions of the poem, I directly borrow the word "prefecture".

“蜀州”, a location, today's Chongzhou in Sichuan Province.

“城阙” refers to Chang'an City, the capital of the Tang Dynasty.

“三秦” is an area called Guanzhong around Chang'an. At the end of the Qin Dynasty, Xiang Yu defeated the Qin's armed forces, divided Guanzhong into three parts and put them under three Qin's generals' administrations who have surrendered to him.

“五津” equals to “蜀州”

These are things that we don't know without the assistance of the Internet. Many of the above mentioned are locations where we may make mistakes. After figuring out these, we can basically guarantee the faithfulness.

“城阙辅三秦, 风烟望五津” means the city of Chang'an was protected by the 
three parts of Guanzhong, Shuzhou can hardly be seen from the wind and ashes. The three locations have to be clear in the translated version.

“与君离别意, 同是宦游人”, you and I have similar destiny, we are both government officials far away from our homes.

“海内存知已, 天涯若比邻”, if we have someone who knows about us so well, we would feel like we're neighbours even we're far away from each other.

“无为在岐路, 儿女共沾巾”, we don't have to cry when we depart.

During the translation, I made many alterations to the version back and forth actually, including the number of the words in each line and the rhyme. The poem is highly refined and concise, which, therefore, makes it harder to keep the number of words in every line the same. In order to make sure the meanings are intact, the translator decided to be less strict in terms of the words' number. Secondly, after linking words into sentences, there are many different ways to interpret, that is to say, many possibilities of words combinations. The high density, grammatical versatility and its tonality lead the Language, Chinese, to wide differences in interpretation, which is particularly observable in terms of translation (Baker, 2004). After many times of translation, the final version is shown in the appendix, by expressing with the least words.

In the appendix, I translated it into four lines despite eight lines in the original text. As we all can see, the meaning is quite simple and clear and it would be quite lengthy if being translated into eight lines, so I chose four. As for the rhyme, neither did the author follow the original text.

\section{Translation Assessment}

\subsection{Self-Assessment}

First of all, the English version is not so good actually due to the author's limited knowledge and experience, and as you may find on the Internet, there already are some English versions available. But I still learned a lot from the practice. Before translation, we need to have a thorough understanding about the background, the author, proper nouns, etc. Because of cultural differences, the Chinese people and foreigners are greatly different from each other. In order to be an excellent translator, we have to know something about everything and know everything about something. There are so many things we don't know in a short poem, what if it is a novel or an essay in a certain field? Through this practice, I realized my great inadequacies in both Chinese and English. There is still a long way to go on my journey to be a great translator.

\subsection{Peer Assessment}

The English version is readable and easy to understand with literary flavor, which is in line with the style of the original text. Proper nouns such as locations are translated correctly. Even though there is no personal noun in the English version, it is still fluent. It can be seen that the translator has put time and heart in the translation. For example, there's something about the English version worth to be mentioned, the rhyme, "ar", which is not commonly seen in trans- 
lated Chinese poems. However, the original text is comprised of eight small sentences with five Chinese Characters each. The English version is good in rhyme, but may do better on the number of the words, which would make the translation closer to the poem. Despite the translator's efforts, some cultural connotations are still lost, for instance, there is a Character, “辅”. It is ok to translate it into "surround", but what the Chinese Character means to Chinese people is different from "surround" to its native speakers. We, as Chinese, think it as a literary word, a word that cannot be usually seen in our daily life. "surround", in another way, is a commonly seen word.

\subsection{Customer Evaluation}

According to the comparison between ST (source text) and TT (target text), the TT accurately expressed the meaning of ST and didn't miss any information element. Due to the ST is a poem, the writer mainly followed the free translation strategy. Although the beauty of the five characters has lost in target text, each line in TT rhymed for "ar", which is very pleased for foreigners to read. Besides, the TT is very smooth and there is no misunderstanding or clumsy sentence in it. So all in all, the TT is very great.

\section{Conclusion}

The poem is not very long. However, many culture factors are hidden in every line, which makes it difficult to find the equivalent expression during translation. Therefore, through the translation practice, I understood that the translation of word and sentence should be flexibly handled to comply with the target readers' language habits, even when the source text is a poem. The version should be readable and in line with the target language.

As the way that Peter Newmark puts it, culture's manifestation is peculiar to a community that uses a particular language as its means of expression (Newmark, 2001). The author has tried to make every line clear in a way that the target readers are familiar with.

What's more, I accumulated some translating experience to share:

Firstly, we should strengthen our translating ability and broaden our horizon. As a communication bridge between the original author and readers, translators must be skilled in both English and Chinese, such as vocabulary, syntax and discourse level. We have to know that translators need to read newspapers and books in English and Chinese in daily exercises or study abroad, watch foreign programs, contact with foreign friends to enhance their understanding of the cultural level.

Secondly, a good translator should be mastered in some computer translating software, for example, Chinese character recognition software ABBY Fine Reader, Dictionaries (Longman English Dictionary Online-LDOCE, Youdao, and so on), Google and Wikipedia. Even the author did not adopt any of these, they are, without doubt, important for translators.

Last but not least, truth comes from practice. There are many translation 
theories, certain kind of them is merely suitable for some kind of or some specific work, instead of a universal one that can be used in all translations. It is the author's belief that such interpretive translation can be adopted in poetry translation for its merits in redisplaying the contents and artistic style, but it also depends.

\section{References}

Baker, M. (2004). Routledge Encyclopedia of Translation Studies. Shanghai: Shanghai Foreign Language Education Press.

Lin Huangtian. 林煌天. (1997). A Companion for Chinese Translators 中国翻译词典. Hubei Foreign Language Education Press, 湖北外语教育出版社.

Newmark, P. (2001). A Textbook of Translation. Shanghai: Shanghai Foreign Language Education Press.

Nida, E. A. (2001). Language and Culture: Contexts in Translating. Shanghai: Shanghai Foreign Language Education Press.

Yang Guoyan, \& Zhang Xinmin. 杨国艳, 张新民. (2005). From the Stylistic Features of the “Zhouyi” See Interpretation of Translation 从“周易”的文体特点看阐释性翻译. Academic Theory of Equilibrium 学术论衡, Shijiazhuang 石家庄.

\section{Appendix}

\section{送杜少府之任蜀州 \\ Seeing Perfect Du off to Shuzhou}

城阙辅三秦, 风烟望五津。 $\begin{aligned} & \text { Shuzhou can hardly be seen from the capital Chang'an surrounded } \\ & \text { by three parts }\end{aligned}$
与君离别意, 同是宦游人。
Reluctance in our hearts because we both are official afar
海内存知己, 天涯若比邻。
Bosom friends also feel close despite the distance apart
无为在岐路, 儿女共沾巾。


Submit or recommend next manuscript to SCIRP and we will provide best service for you:

Accepting pre-submission inquiries through Email, Facebook, LinkedIn, Twitter, etc. A wide selection of journals (inclusive of 9 subjects, more than 200 journals)

Providing 24-hour high-quality service

User-friendly online submission system

Fair and swift peer-review system

Efficient typesetting and proofreading procedure

Display of the result of downloads and visits, as well as the number of cited articles Maximum dissemination of your research work

Submit your manuscript at: http://papersubmission.scirp.org/

Or contact chnstd@scirp.org 